\title{
WATER USE INFORMATION SYSTEM
}

The Hanford Engineering Development Laboratory, under sponsorship of the U.S. Department of Energy, has developed a Water Use Information System (WUIS) to help you plan energy strategy.

WUIS provides data for each Water Resource Cataloging Unit division in the contiguous United States. Data are available on cooling water requirements for all central station electric power plants.

WUIS provides data for power system planners to make initial assessments of the availability of water for cooling electrical power generating facilities.

WUIS data are available for each of the eight-digit Water Resource Cataloging Unit Code, as shown in the illustration below. Data on water resources are tabulated for each Cataloging Unit. Data on electrical power plants are tabulated by state and county, as well as by Cataloging Unit.
The water resource element of the information system contains four basic types of data: area description; surface water; ground water; and oceans or bays falling within the Cataloging Unit. Table I summarizes the water resource data included for each Cataloging Unit.

Table II summarizes the data available on electrical generating plants. These data are provided for thermal power plants of $100 \mathrm{MWe}$ rating or greater; for convenience, applicable data for hydroelectric plants are also given.

HEDL is also developing an auxiliary computerized model, which, used in conjunction with the information system, will provide projections of future water use data. These predictive features are available in preliminary form; full capability will be available by late 1979

Fees for retrieval of data are on a cost-recovery basis according to established Department of Energy policies.
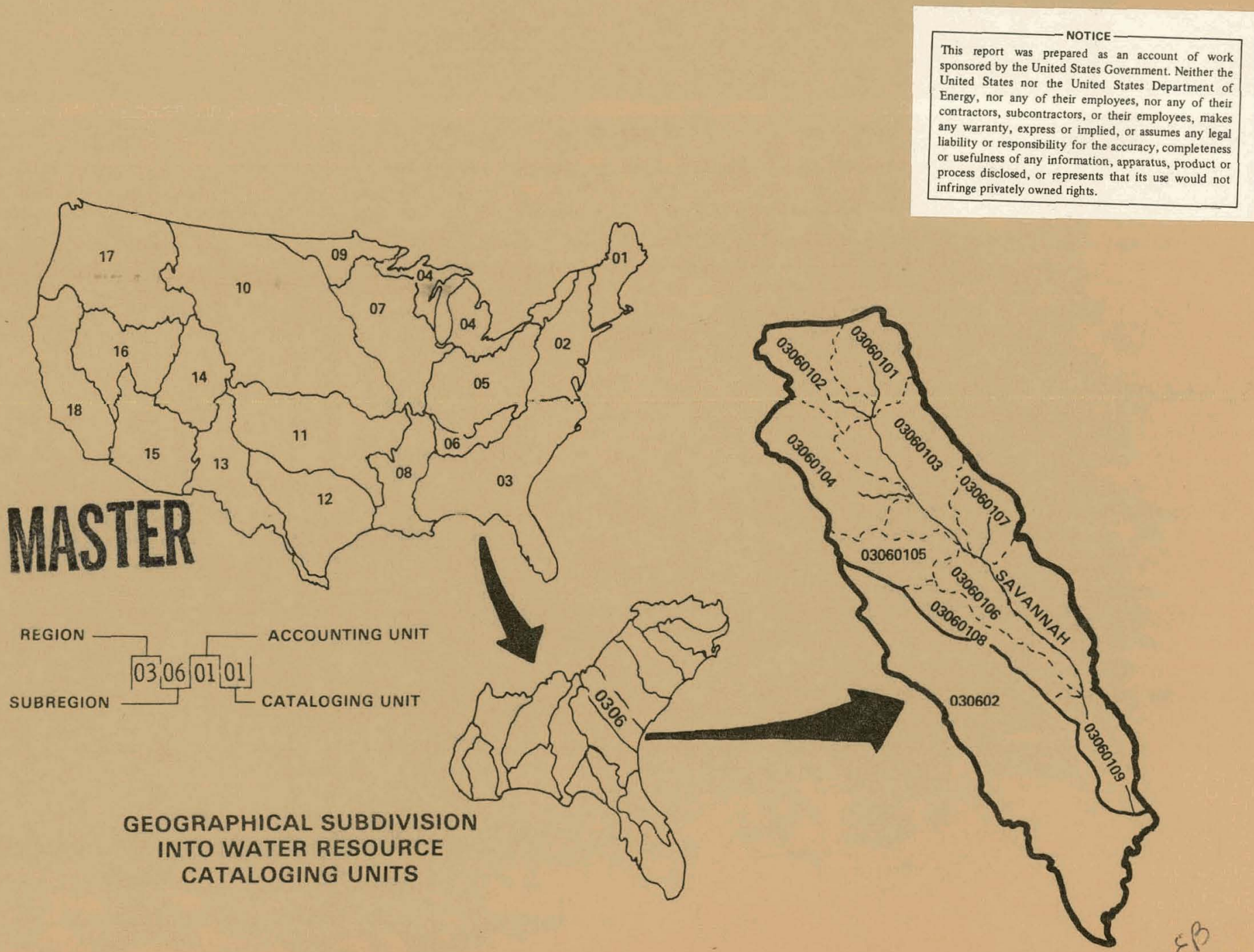


\section{DISCLAIMER}

This report was prepared as an account of work sponsored by an agency of the United States Government. Neither the United States Government nor any agency Thereof, nor any of their employees, makes any warranty, express or implied, or assumes any legal liability or responsibility for the accuracy, completeness, or usefulness of any information, apparatus, product, or process disclosed, or represents that its use would not infringe privately owned rights. Reference herein to any specific commercial product, process, or service by trade name, trademark, manufacturer, or otherwise does not necessarily constitute or imply its endorsement, recommendation, or favoring by the United States Government or any agency thereof. The views and opinions of authors expressed herein do not necessarily state or reflect those of the United States Government or any agency thereof. 


\section{DISCLAIMER}

Portions of this document may be illegible in electronic image products. Images are produced from the best available original document. 


\section{TAB:LE I}

\section{DATA PROVIDED FOR EACH 8-DIGIT WATER RESOURCE CATALOGING UNIT}

\section{AREA DESCRIPTION INCLUDES}

- APPROXIMATE AREA (SO MI)

- STATE AND DOMINANT COUNTY

- APPROXIMATE AREA POPULATION

- aVERAge, MIN AND MAX RUNOFF

- WATER RIGHTS STATUS AND COMPETING

WATER USE DATA WILL BE AVAILABLE 1980

\section{SURFACE WATER}

- RIVERS (4 MAX/CATALOGING UNIT)

- NAME

- average annual flow (cfs)

- FLOW BY MONTH FOR 50, 90 AND $95 \%$ PROBABILITY

- TOTAL DISSOLVED SOLIDS, HARDNESS

- temperature (MEAN, MAX, MIN)

- LAKES OR RESERVOIRS (4 MAX/CATALOGING UNIT)

- NAME

- AREA

- VOLUME
- MEAN, MAX AND MIN TEMPERATURES

- TOTAL DISSOLVED SOLIDS, HARDNESS AND $\mathrm{pH}$

GROUND WATER IMAX OF 4 AQUIFERS/SUB-SUB REGION)

- aquifer code

- aQUifER ROcK TYPE \& DESCRIPTION

- GROUND WATER REGION

- DEVELOPMENT STATE (RECHARGE - OVERDRAFT)

- DEPTH BELOW GROUND LEVEL, MAX, MIN

- AQUIFER THICKNESS, MAX, MIN

- SPECIFIC CAPACITY, MAX, MIN (GAL/FT/HR)

- AREAL EXTENT (SO MI)

- YIELD, MAX, MIN (gpm)

- TEMPERATURE, MAX, MIN

- TOTAL DISSOLVED SOLIDS, MIN, MAX (ppm) AND pH

- WATER RIGHTS (NARRATIVE)

OCEAN/BAY (I/CATALOGING UNIT)

- NAME

- SALINITY

- MEAN, mAX AND MIN TEMPERATURE

TABLE II

GENERATING PLANT DATA

DATA ARE PROVIDED FOR EACH THERMAL GENERATING PLANT WITH RATINGS

OF 100 MWe OR GREATER. APPLICABLE DATA FOR

HYDROELECTRIC UNITS ARE INCLUDED FOR CONVENIENCE.

\section{GENERAL PLANT INFORMATION}

- PLANT NAME

- UTILITY NAME

- PLANT LOCATION, INCLUDING

- CITY, COUNTY AND STATE

- WATER RESOURCE CATALOGING UNIT

- LATITUDE AND LONGITUDE

- FPC POWER SUPPLY AREA \& REGION

- PLANT TYPE

- PLANT CAPACITY (MWe)

- FIRST YEAR OF COMMERCIAL OPERATION

\section{PLANT COOLING INFORMATION}

- TYPE (ONCE-THROUGH, TOWER, ETC.)

- COOLING WATER SOURCE

- FLOW RATE OF RECEIVING WATER BODY

- WITHDRAWAL, CONSUMPTION, BLOWDOWN, DISCHARGE RATES

PLANT OPERATION DATA (YEARLY)

- generation

- heAT RATE

- CAPACITY FACTOR

HANFORD ENGINEERING DEVELOPMENT LABORATORY Operated by Westinghouse Hanford Company P.O. Box 1970 Richland, WA 99352 A Subsidiary of Westinghouse Electric Corporation Prepared for the U.S. Department of Energy under Contract No. EY-76-C-14-2170 